\title{
MULHERES, BENEFICÊNCIA E LOUCURA: UMA HISTÓRIA SOCIAL COM PERSPECTIVA DE GÊNERO
}

Women, charity and insanity: a social history from the perspective of gender

\author{
ANAHÍ GUADALUPE PAGNONI \\ La casa de las Locas: una historia social \\ del Hospital de Mujeres Dementes: \\ Buenos Aires, 1852-1890 \\ Valeria Silvina Pita
}

Rosario: Prehistoria Ediciones, 2012

http://dx.doi.org/10.1590/S0103-21862015000100014

Anahí Guadalupe Pagnoni é professora de História da Facultad de Humanidades y Arte - Universidad Nacional de Rosario (anahipagnoni@hotmail.com).

Resenha recebida em 12 de novembro de 2014 e aprovada para publicação em 27 de março de 2015. 
A autora explora o surgimento e a constituição do primeiro manicômio de muIheres de Buenos Aires na segunda metade do século XIX. O livro se situa historiograficamente na história social com perspectiva de gênero, com o objetivo de restituir as mulheres à história e refletir sobre como o gênero e as relações entre homens e mulheres uniram perspectivas e práticas no passado. Pita incorpora as leituras da historiografía social latino-americana sobre Michel Foucault e Robert Castel com respeito ao controle social e à incorporação de novos atores sociais, para além dos trabalhadores. E nesta chave ela traz uma contribuição ao examinar o grau de efetividade das políticas de controle social e seu impacto nas vidas dos destinatários.

Em 1854, as damas portenhas integrantes da Sociedad de Beneficencia valeram-se das vicissitudes políticas que a província atravessava para concretizar um acalentado projeto. Ao se encarregarem do Hospital de Mujeres de la Ciudad de Buenos Aires, elas se dispuseram a criar um hospício próprio para as mulheres consideradas dementes. A causa das mulheres dementes foi tomada como estandarte da caridade pública, e com ela as damas da beneficência lograram não só abrir o hospício como convertê-lo numa questão política que deveria ser apoiada pelo governo portenho. A estratégia usada pelas damas para se (re)colocarem no mapa político portenho posterior à Batalha de Caseros (re)posicionou o papel social da beneficência pública perante as novas autoridades.

Por esses motivos, Pita não compartilha a visão historiográfica que considera a Sociedad de Damas de Beneficencia como uma instituição privada à margem da organização governamental, que apenas recebia apoio financeiro do Estado. A autora (re)define o papel social da associação como uma agência estatal composta por mulheres da elite portenha que se refugiou na órbita política provincial para logo passar à estatal. Ela mostra como as sucessivas gerações de damas da beneficência, com base na sua função de administradoras do Hospício, construíram um espaço de participação na conformação da estrutura do Estado. Da mesma forma, seu papel público sob o amparo de uma administração do Estado lhes permitiu tomar decisões de ordem coletiva, bem como controlar recursos. Numa sociedade em que os postos políticos eram de domínio masculino, a atuação ativa das "damas" no mundo associativo complexifica nossa visão da construção da mulher como sujeito da participação política. 
Por outro lado, a batalha das damas se travou não só na vida pública, como no interior do manicômio. A tarefa de organização do hospício não foi simples; exigiu que se acomodassem as opiniões contrárias das participantes, seus conflitos, e que se chegasse a um acordo quanto à base do programa assistencial. As práticas e intervenções dessas mulheres poderosas com suas distintas iniciativas na vida social determinavam quem seria incluído e excluído delas, qual era a forma de ajuda aos pobres e como elas viam a sua ação na beneficência pública. Seu pertencimento à elite portenha nos mostra de que maneira essa classe social voltou a dar sentido aos parâmetros da exclusão social. Os acordos, negociações e contendas que as envolvem lançam luz sobre como o Estado ensaiava respostas diante da marginalidade, da doença e da pobreza.

Pita transita pelos pavilhões do hospício para indagar quem e em que condições era confinada ali. Essas perguntas expõem diante dos nossos olhos o cotidiano do lugar, um espaço de experiências onde, entre o consenso e a disputa, se manifesta um conjunto de práticas próprias do confinamento. Os fragmentos da vida em reclusão das doentes são pacientemente alinhavados com a ajuda de uma variedade de fontes pouco utilizadas em outros estudos institucionais (artigos médicos na imprensa, publicações científicas, rastros das pacientes, fichas de ingresso, diagnósticos de loucura etc.). Esses indícios configuram a rede de que fazem parte as "dementes" e seus responsáveis, tanto as damas da beneficência quanto suas cuidadoras, médicos e diferentes membros do Estado.

A loucura foi utilizada para difundir um discurso e uma intervenção médica que a ligou à periculosidade social. A partir de 1860 o conjunto de excluídas adquiriu novas dimensões, quando os juízes aprovaram o cumprimento de condenações penais na instituição. Um novo grupo de mulheres, as rés, veio aumentar o número internas. A presença das presas na instituição desencadeou a disputa entre as damas da beneficência e os juízes provinciais para determinar que tipo de mulheres deveria se internar. Invisíveis do lado de fora, heterogêneas do lado de dentro, cada paciente era uma história de como esconder, atrás dos muros, a pobreza. As damas e o Estado, através do confinamento, trataram de reprimir um amplo grupo de mulheres marginais, influindo na correção de suas condutas e ao mesmo tempo dando uma resposta à pobreza urbana. Pita dialoga com as notícias historiográficas de controle social para esquadrinhar o grau de efetividade das políticas do Estado e como as pessoas às quais elas se destinaram reelaboraram ou parcializaram sua influência sobre suas vidas.

No final do século XIX, as relações no interior do hospício se reconfiguraram novamente; um novo grupo de médicos havia se formado na Faculdade de Medicina e, guiado pelo alienalismo, batalhou para impor os preceitos científicos nas medidas tomadas pelo Estado para a assistência pública. A situação para as damas não ficou nada fácil; dentro da associação 
havia atritos entre as integrantes, a situação política portenha sofria percalços que influíam nas instituições provinciais, e a nova corporação científica lutava para impor seus próprios preceitos na direção da instituição. Sem dúvida, as damas saíram-se bem e fortalecidas, e paulatinamente se incorporou no manicômio o ideário científico sem entrar em contradição com o papel de reclusão da loucura e da pobreza que ele vinha cumprindo.

A profissionalização médica é complexificada pela autora à luz de estudos que não viram nela um campo uniforme e sem fissuras. A velha visão de uma "ordem psiquiátrica" dominante é deixado para trás para se examinar os claro-escuros das ações das elites científicas e estatais, nem sempre unidirecionais. Pita se afasta das visões historiográfícas que postulavam um poder médico consolidado e açambarcador de recursos que impôs seus projetos de reforma e modernização. Em seu lugar, enriquece a compreensão da prática médica como um contínuo trabalho desses profissionais em diferentes locais - cátedras, Assistência Pública, periódicos etc. - para lograr um consenso capaz de dar valor à sua posição.

Por volta de 1890, momento de conclusão do livro, a velha Convalecencia se tinha transformado numa instituição nacional. 0 Manicômio Nacional, com a ampliação de funções, funcionários e pacientes, gerou uma série de tensões entre suas antigas encarregadas, os médicos e os representantes do poder nacional. Numa assistência pública programada com aspirações nacionais se pôs em dúvida como seus diferentes protagonistas entendiam seus sentidos, tensões, expectativas e incertezas. A Casa de las Locas complexifica e permite visualizar uma história que todos conhecemos mas que sempre tinha sido enfocada a partir de um único ponto. 0 hospício, em sua relação com uma sociedade em contínua transformação, influiu na construção de um Estado insipiente que requeria um arcabouço assistencial. Em seu papel de agente estatal, o manicômio marcou quem e porque era apta a fazer parte da nova cidadania política. Para nos encontrarmos com as damas e as loucas, devemos apenas transpor os muros... 